\title{
Focal Megalencephaly with Tuberous Sclerosis Complex Magnetic Resonance Imaging Findings: A Case Report
}

\author{
Fokal Megalensefalinin Eşlik Ettiği Tuberoskleroz Kompleksinin Manyetik Rezonans \\ Görüntüleme Bulguları: Olgu Sunumu
}

\author{
Özdil Başkan¹, Ece Gültekin², Fatma Gamze Demirel², Güzide Turanlı² \\ ${ }^{1}$ Medipol University School of Medicine, Department of Radiology, İstanbul, Turkey \\ ${ }^{2}$ Medipol University School of Medicine, Department of Pediatric Neurology, İstanbul, Turkey \\ ${ }^{3}$ Medipol University School of Medicine, Department of Pediatrics, İstanbul, Turkey
}

\section{Summary}

Hemimegalencephaly (HME) is a rare cortical developmental anomaly that can be defined as abnormal neural and glial proliferation localized to all or part of a cerebral hemisphere. Tuberous sclerosis complex (TSC) is an autosomal dominant, multisystem disease that most frequently involves the central nervous system, skin, heart, kidneys, and eyes. Herein, we report the magnetic resonance imaging findings of a rare case of focal megalencephaly with TSC.

Keywords: Tuberous sclerosis complex, hemimegalencephaly, magnetic resonance imaging

$\ddot{O} \mathbf{z}$

Hemimegalensefali serebral hemisferin tamamının veya bir kısmının etkilendiği anormal nöral ve glial proliferasyon ile tanımlanabilen ender bir kortikal gelişimsel anomalidir. Tuberoskleroz kompleksi (TSK) otozomal dominant geçişli, başta santral sinir sistemi olmak üzere kalp, böbrek, göz ve cildi tutan multisistem hastalığıdır. Çalışmamızda ender olarak görülen fokal megalensefalinin eşlik ettiği TSK olgusunun manyetik rezonans görüntüleme bulgularını sunmayı amaçladık.

Anahtar kelimeler: Tuberoskleroz kompleksi, hemimegalensefali, manyetik rezonans görüntüleme

\section{Introduction}

Hemimegalencephaly (HME) is a rare condition of hamartomatous overgrowth localized to all or part of a cerebral hemisphere $(1,2)$. Clinical presentation is often in the form of drug-resistant epilepsy. Patients may have asymmetrical cranial overgrowth, marked developmental retardation, hemiplegia, and hemianopia. The most common findings of magnetic resonance imaging (MRI) include increased parenchymal size, cortical dysplasia, and blurring of the gray and white matter boundary (2).

Tuberous sclerosis complex (TSC) is an autosomal dominant neurocutaneous disorder seen in one per 6000 live births (3). This is a multisystemic disease that particularly involves the central nervous system, followed by the heart, kidneys, eyes, and skin. Features of intracranial involvement are the major determinants of its clinical course. Cranial involvement is characterized by cortical tubers, subependymal nodules (SEN), subependymal giant cell tumors and various white matter lesions (4).

We present herein the magnetic resonance imaging findings in a case of hemimegalencephaly and tuberous sclerosis.

\section{Case Report}

A male infant was delivered through cesarean section with a birth weight of 4200 grams. He was born to parents with no consanguinity as the second live child of 3 gravida, and admitted to the newborn intensive care unit of our hospital because of intrauterine cardiac rhabdomyoma and hypomotor seizures, which had started on the second day of life and lowered saturation. Phenobarbital therapy was maintained. Physical and neurologic 
examinations were insignificant. An electroencephalograph (EEG) recording that was performed because of focal motor seizures with clonic right arm jerking on the second day of admission showed disorganization in background activity in all electrode areas, as well as an epileptiform abnormality originating from the posterior hemispheric regions. Cranial magnetic resonance imaging (MRI) was obtained upon observation of this very active focal epileptiform area, as well as cortical tubers and right hemispheric cortical thickening in routine cranial ultrasonography.

MRI was performed while the infant was under anesthesia using an Achieva $3 \mathrm{~T}$ MR (Philips Best, Netherlands) after obtaining consent of parents. Contrast material could not be used due to the patient's age. Magnetic resonance imaging revealed cortical thickening in the frontoparietal region in the right hemisphere, sulcal effacement, agyria-pachygyria appearance, an indistinguishable corticomedullary junction, hyperintensity in neighboring white matter in T1-weighted images, and hypointensity in T2-weighted images. Neighboring lateral ventricles were enlarged with irregular boundaries (Figure 1).

Cortical tubers were visualized as hypointensities in $\mathrm{T} 2 \mathrm{~W}$ sequences and hyperintensities in T1W sequences on the inferior of the right frontal lobe and medial of the left frontal lobe, characterized by cortical thickening and an indistinguishable cortical white matter junction. White matter dysmyelinations appearing as focal linear, and hyperintense areas on T1W were also noted. Subependymal nodules were observed bilaterally at the inferior of frontal horns, at the level of foramen Monro as hypointensity in T2W and hyperintensity in T1W sequences (Figure 1).

Altogether, these findings led to a diagnosis of TSC accompanied by focal megalencephaly.

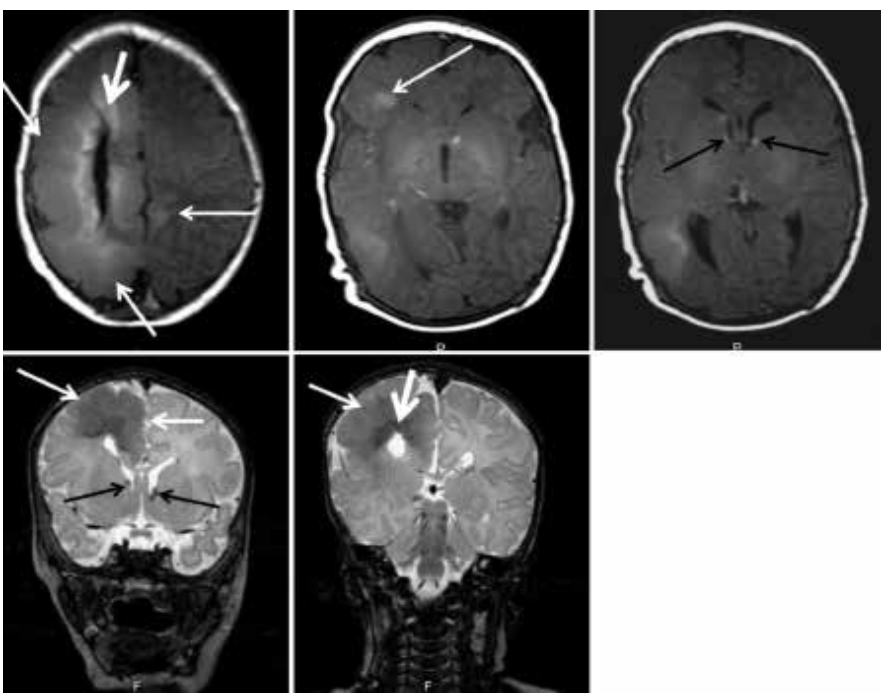

Figure 1. Frontoparietal cortical thickening, sulcal effacement, agyriapachygyria appearance, indistinguishable corticomedullary junction, signal changes in neighboring white matter (arrows) in right cerebral hemisphere. Enlargement and irregular boundaries of ipsilateral lateral ventricle are also seen (thick arrows). Cortical tubers are seen in the inferior of right frontal lobe and next to the cerebral falx in the medial of left frontal lobe (long arrows). Bilateral subependymal nodules are seen in the inferior of frontal horns and foramen Monro (black arrows)

\section{Discussion}

HME is a cortical developmental abnormality characterized by unilateral overgrowth and dysplasia of the cerebral hemisphere (5). HME often involves a single cerebral hemisphere, but sometimes only part of the hemisphere may be involved, which leads to the description of 'focal megalencephaly'(4). The etiology is unknown, and several mechanisms are involved in the pathogenesis, including abnormal neuroglial proliferation $(5,6)$. HME has characteristic neuro-imaging findings. MRI shows cerebral enlargement accompanied by ventricular enlargement on the effected side, and an indistinguishable cortical white matter boundary. Cortical dysplasia (polymicrogyria or lissencephaly) may also co-occur. The corpus callosum appears symmetrical and enlarged on the effected side; however, bilateral hypoplasia or agenesis of corpus callosum may also be seen.

TSC is a rare neurocutaneous disease that often presents with mental retardation and epilepsy. Although TSC is classically diagnosed with the Vogt triad, which comprises adenoma sebaceum, epilepsy, and mental retardation, recent diagnostic criteria have been constituted that encompass multisystemic involvement (7). In our case of TSC, diagnosis was established upon demonstration of intracranial cortical tubers and accompanying SEN and cardiac rhabdomyoma. The MRI findings included multiple corticalsubcortical tubers, SEN, typical linear signalization changes in white matter, and subependymal giant cell astrocytoma, which were diagnostic. MRI is the preferred evaluation modality for cerebral parenchyma; however, identification of calcified SEN and cortical-subcortical tubers in computed tomography are also diagnostically valuable (7).

Our case had findings in line with focal megalencephaly delineated as increased frontoparietal size in the right cerebral hemisphere; cortical thickening; agyria-pachygyria appearance; ipsilateral ventricular enlargement and contour irregularity; TSC characterized by cortical tubers in bilateral frontal lobes; and bilateral SEN in the frontal horns and foramen Monro. Similar cases have been reported in the literature $(2,4,8,9)$.

Advancement of neuroradiologic imaging has enabled detailed investigation and description of several intracranial pathologies. In the study of Barkovich et al on the classification of cortical developmental abnormalities, HME and TSC were grouped under cortical dysgenesis, characterized by abnormal neuronal and glial cell proliferation and absence of tumoral processes $(6,10)$. According a study performed in 2005, HME was classified into two categories, the isolated form, and the form associated with neurocutaneous disorders (10). However, the revised classification of 2012 separates HME into three types: isolated, associated with neurocutaneous disorders, and those associated with TSC (6). The same study underlined that this classification may be restructured following detailed case investigations. Consequently, it is important to note that the intracranial congenital pathologies in particular may co-occur and investigations should be carefully interpreted in order to contribute towards more accurate future classifications.

Patient Consent: Written informed consent was obtained from the patient. Concept: Özdil Başkan, Ece Gültekin, Fatma Gamze Demirel, Güzide Turanlı, Design: Özdil Başkan, Güzide Turanlı, Data Collection or Processing: Özdil Başkan, Ece 
Gültekin, Fatma Gamze Demirel, Güzide Turanlı, Analysis or Interpretation: Özdil Başkan, Güzide Turanlı, Literature Search: Özdil Başkan, Writer: Özdil Başkan, Peer-review: Internal peer-reviewed. Conflict of Interest: Authors declare no conflicts of interest regarding this manuscript. Financial Support: Our study has not received financial supports from any institution or person.

\section{References}

1. Kalifa GL, Chiron C, Sellier N, Demange P, Ponsot G, Lalande G, Robain O. Hemimegalencephaly: MR imaging in five children. Radiology 1987;165:29-33.

2. Gupta A, Carreno M, Wyllie E, William EB. Hemispheric malformations of cortical development. Neurology 2004;62(Suppl 3): 20-26.

3. Guerra MP, Cavalleri F, Migone N, Lugli L, Delalande O, Cavazzuti GB, Ferrari F. Intractable Epilepsy in Hemimegalencephaly and tuberous sclerosis complex. J Child Neurol 2007;22:80-84.
4. Griffiths PD, Gardner SA, Smith M, Rittey C, Powell T. Hemimegalencephaly and focalmegalencephaly in tuberous sclerosis complex. AJNR Am J Neuroradiol 1998;19:1935-1938.

5. Flores-Sarnat L. Hemimegalencephaly: Part 1. Genetic, clinical, and imaging aspects. J Child Neurol 2002;17:373-384.

6. Barkovich AJ, Guerrini R, Kuzniecky RI, Jackson GD, Dobyns WB. A developmental and genetic classification for malformations of cortical development: update 2012. Brain 2012;135:1348-1369.

7. Gomez MR. Diagnostic criteria. In: Gomez MR, ed. Tuberous sclerosis. 2nd ed. New York, NY: Raven, 1985;9-20.

8. Galluzzi P,Cerase A, Strambi M, BuoniS, Fois A, VenturiC. Hemimegalencephaly in tuberous sclerosis complex. J Child Neurol 2002;17:677-680.

9. Parmar H, Patkar D, Shah J, Patankar T. Hemimegalencephaly with tuberous sclerosis: a longitudinal imaging study. Australas Radiol 2003;47:438-442.

10. Barkovich AJ, Kuzniecky RI, Jackson GD, Guerrini R, Dobyns WB. A developmental and genetic classification for malformations of cortical development. Neurology 2005;65:1873-1887. 